Article

\title{
Evaluation of Groundwater Overdraft Governance Measures in Hengshui City, China
}

\author{
Yong Zhao®, Lizhen Wang *, Haihong Li, Yongnan Zhu®, Qingming Wang, Shan Jiang, \\ Jiaqi Zhai and Peng Hu* \\ State Key Laboratory of Simulation and Regulation of Water Cycle in River Basin, China Institute of Water \\ Resources and Hydropower Research, Beijing 100038, China; zhaoyong@iwhr.com (Y.Z.); lihh@iwhr.com (H.L.); \\ zhyn@iwhr.com (Y.Z.); wangqm@iwhr.com (Q.W.); shan_jiang87@126.com (S.J.); jiaqizhai@163.com (J.Z.) \\ * Correspondence: wanglzh@iwhr.com (L.W.); hp5426@126.com (P.H.)
}

Received: 2 March 2020; Accepted: 23 April 2020; Published: 27 April 2020

\begin{abstract}
Groundwater overdraft is a worldwide phenomenon, resulting in environmental issues, such as water contamination, land subsidence, seawater intrusion, streamflow reduction, and deterioration of the ecological environment. Located in the central North China Plain, Hengshui City has experienced a regional groundwater depression cone due to excessive pumping of groundwater, resulting in the largest overdraft area in the North China Plain. Since 2014, Hebei Province has adopted measures to realize the comprehensive governance of groundwater overdraft in partial areas of Hengshui City, including adjusting planting structures, promoting agronomic water-saving techniques, strengthening hydraulic engineering construction, and innovative management systems. These measures have been in effect for two years, such that their effectiveness must be assessed for the beneficial recovery of groundwater levels to determine the means for their continuation and extension. However, the change in regional groundwater levels is not gradual, but reflects a process of sudden increase due to the intervention of government behavior, and many existing groundwater recharge models are difficult to apply. Therefore, establishing a reasonable, scientific evaluation system of the measures is a key problem that requires a solution. Using field surveys and experiments, this study establishes a quantitative analysis evaluation method to assess the performance of governance measures adopted by Hengshui City in 2015, with full consideration of the crop water demand process and rainfall frequency. The results show that governance measures had a significant positive outcome on reducing groundwater overdraft in pilot areas. Approximately $98.4 \%$ of the agricultural governance target was achieved, with confined groundwater rebounding by approximately $4.92 \mathrm{~m}$ as compared to 2015 . According to the analysis, the three most efficient measures (the top three largest amounts of groundwater-saved per mu) adopted by the government were (1) non-agricultural crops replacement (forestry), (2) planting pattern adjustments, and (3) integration of water and fertilizer-vegetable, which can be promoted in future measures. However, considering the size of the implementation area and total governance capacity, water-saving during spring irrigation of wheat and replacement by surface water are the two most important conservation measures, which are required to further strengthen the management and implementation effect.
\end{abstract}

Keywords: groundwater overdraft; comprehensive governance; effect evaluation; groundwater level; agronomy water-saving techniques; regional groundwater depression cone

\section{Introduction}

As a fundamental component of the water cycle, groundwater is of paramount importance in supporting human economic and social development. However, due to climate change and the influence of human activities, groundwater resources have been heavily depleted in many parts 
of the world. For example, in the USA, groundwater meets $75 \%$ of the municipal water demand and provides drinking water for more than half of the population [1]. Due to their arid, semi-arid, and semi-humid climates, seventeen northern provinces in China regularly experience severe water shortages, failing to meet the water demand of industrial and agricultural production and domestic use [2]. Since the 1970s, groundwater resources in this region have been widely exploited, with annual increases in groundwater withdrawals of 2.5 billion $\mathrm{m}^{3}$ during the last 30 years. Consequently, over 100 groundwater depression cones have formed across an area of 150,000 $\mathrm{km}^{2}$. The area of groundwater overdraft approaches $620,000 \mathrm{~km}^{2}$ and approximately 60 cities have been categorized as seriously over-exploited [3]. Groundwater overdraft has attracted considerable attention due to its harmful environmental and economic consequences, as well as its beneficial socioeconomic effects [4]. The negative impacts of groundwater overdraft include uneconomic pumping conditions; water quality degradation via the intrusion of saline or poor-quality groundwater; flow reduction in streams, wetlands, and springs; land subsidence; interference with pre-existing water use and water rights; and a gradual depletion of groundwater storage $[5,6]$. Considering the magnitude of the problem and its consequences, groundwater overdraft issues have been extensively discussed and legal restrictions implemented.

Water governance has emerged as an important topic in the international arena and is acknowledged to be a crucial factor for adequate and sustained progress towards achieving sustainability [7]. Early in 1980, the Groundwater Management Act resolved legal disputes over rights to groundwater, and established programs to reduce groundwater overdraft and the resulting water level declines in Arizona, which have had mixed success [8]. Therefore, effective and comprehensive groundwater governance is very important to minimize the social, economic, and environmental effects of the problems derived from the groundwater overdraft. The concept of water governance was discussed and evolved widely and thoroughly in recent years, and it is clear that governance is a prerequisite for improving water management [9]. Governance can be defined as "the process of decision-making and the process by which decisions are implemented (or not implemented)" [10]. The World Bank report sets out the definition of good governance as the manner in which power is exercised in the management of a country's economic and social resources for development [11]. Jiménez et al. [7] proposed a sustainable approach and structure of good governance, i.e., "Water governance is a combination of functions, performed with certain attributes, to achieve one or more desired outcomes, all shaped by the values and aspirations of individuals and organizations." These different components are described in detail to construct an operational framework to improve water governance, achieving environmental, social, and economic goals. Ekardt et al. compared the command and control options with economic policy options, and the most effective policy (or governance) approach is identified in terms of peatlands [12]. As groundwater always covers large areas, a key problem that cannot be ignored in practical management is the communication and resolution of conflicts between different regions and agents. Social capital is increasingly recognized as the key to both the successes and failures in natural resource management. López-Gunn [13] focused on the social networks aspect of social capital, which is divided into three categories: bonding, bridging, and linking in groundwater governance of two neighboring aquifers in central Spain. López-Gunn [13] concluded that careful institutional design can help foster strong 'positive' social capital, which, in turn, favors self-governance of groundwater. Focusing on the valuation of environmental services, de Castro Pardo et al. [14] proposed a 5-stage methodology for multi-criteria analysis to assign priorities to ecosystem services in protected areas in terms of importance and vulnerability. The results show that conservation policies should be primarily directed towards lifecycle maintenance and water conditions. Sophocleous [15] summarized several innovative management approaches in the eight high plains states of the USA as good examples for emulation in managing groundwater resources. However, fragmented and piecemeal institutional arrangements for managing the supplies and quality of water are inadequate to meet water challenges of the future. The formation of an interstate groundwater commission was recommended. 
Current research on groundwater overdraft can be divided into five categories. Research has focused on the environmental, economic, and social impacts of groundwater overdraft. These studies offer solutions and methods to mitigate negative impacts associated with groundwater overdraft. For example, Zektser et al. [16] compared several American case studies focused on four main impacts of groundwater extraction (streamflow reduction, reduction of vegetation, land subsidence, and seawater intrusion into coastal aquifers), proposing relevant methods to alleviate such impacts. Furthermore, Wolfgang [17] concluded that lower water tables eventually culminate in environmental and ecological problems.

Secondly, previous studies have evaluated methods to determine the vulnerable degree and spatial distribution of groundwater overdraft. For example, Corwin et al. [18] used index-based approaches to create maps based on geographic information systems (GIS), which can store, retrieve, organize, analyze, and present geographically referenced spatial data. Gogu et al. [19] and Zwahlen [20] present several recent vulnerability mapping methods. Index and overlay methods are based on the assumption that a few major parameters largely control groundwater vulnerability, where these parameters are known and can be evaluated. Furthermore, Basil et al. [21] established a model to evaluate overdraft vulnerability using five factors (net recharge, pumping rate density, drawdown, aquifer thickness, and aquifer hydraulic conductivity) to analyze the controlling factors with help from GIS techniques.

Thirdly, studies have examined mitigation strategies to reduce groundwater overdraft, including policy-making and artificial recharge. For example, Kulkarni et al. [22] proposed that governments should manage groundwater as a "common pool" resource to realize efficient, equitable, and sustainable groundwater management. Research in this category postulates that society should respond to groundwater depletion by augmenting, conserving, and reallocating existing supplies [23,24]. Scott et al. [25] suggested that agricultural electric power supply and electricity price policies are the drivers of groundwater exploitation, concluding that adjustments to these policies can significantly improve overdraft conditions. Furthermore, Cory et al. [26] used a linear programming model to analyze variations in groundwater consumption and agricultural income to evaluate the performance of policies on restricting over-exploitation in the Phoenix Active Management Area. They found that an agricultural conservation program was of limited use to restore groundwater resources, whereas the abolition of agricultural lands has proven to be highly effective. In addition, Kimrey [27] introduced a method of artificial groundwater recharge, finding it to be suitable for the management of groundwater overdraft.

The fourth research classification has focused on the development of models to optimize the conjunctive use of groundwater and surface water [28]. For example, Harou et al. [29] used a hydro-economic optimization model to study the economic effects and water management actions that accompany the end of overdraft. They illustrated that overdraft solutions often involve the entire water resource system because we must account for lost water supply. They found that the conjunctive use of surface and groundwater was the best strategy to stop overdraft with the least amount of increase in the water-scarcity cost. By contrast, MacEwan et al. [30] found that the agricultural economy, groundwater, and surface water systems were the critical factors in the sustainable management of groundwater basins.

Research has also focused on socio-economic impacts in regions where groundwater resources have already been over-exploited. Harou et al. [31] paid special attention to economic influences and proposed corresponding water resources management strategies. Furthermore, Davidsen et al. [32] used a hydro-economic modeling approach to find cost-optimal sustainable surface water and groundwater allocation strategies for a river basin given an arbitrary initial groundwater level in the aquifer. To date, studies have mainly concentrated on the methods, such as policy-making or modeling, to help alleviate problems caused by groundwater overdraft. However, there is still a lack of knowledge as to whether these methods are actually considered to be successful. 
Fifth, groundwater recharge and recovery were evaluated and analyzed by building a model [33] and using relevant data, such as geo-processed spatial and climatological data [34]. Scanlon et al. [35] presented a comprehensive overview of the physical, chemical, and mathematical techniques for recharge estimation and water transfer during the infiltration process. These techniques are classified according to the zone to which they apply (surface, unsaturated, or saturated zone) and to their application scale, both spatial (local or regional scale) and temporal (short- or long-term). Demlie [36] adopted two commonly applied groundwater recharge estimation techniques, i.e., the soil-water balance (SWB) and chloride mass balance (CMB) methods, to quantify and analyze groundwater recharge in the Akaki catchment, comparing the difference in the results between the two methods. Numerous studies have calculated the recharge rate of groundwater, suggesting that the results of groundwater recharge are significantly affected by precipitation and climate change [37,38]. However, studies have suggested that it is no longer appropriate to use a single recharge value for an entire watershed calculated as an assumed fraction of the average annual precipitation or as determined by model calibration [39].

Considering the serious groundwater overdraft situation in northern China, the Hebei provincial government adopted various measures to comprehensively treat the groundwater over-exploitation situation in 2014 and 2015, mainly focused on two aspects: (1) increasing the supply of surface water by strengthening water conservancy construction projects to reduce the use of groundwater resources; and (2) adjusting the agricultural planting structure and promoting agronomy water-saving techniques to reduce overall water consumption. After these comprehensive treatments, the amplitude of the groundwater levels and the real exploitation volume of the groundwater were the issues of concern for government decision-makers, which were also regulated as the basis to determine the effect that governance has on groundwater. However, it remains that establishing a reasonable, scientific evaluation system is the key problem to be solved.

Compared with previous studies, our evaluation of groundwater overdraft governance measures has the following three characteristics:

(1) Data availability is limited. There is no long-term observation data and no observation data from the surrounding area for influential factors, such as rainfall timing, intensity, and quantity; antecedent soil moisture conditions; properties of the soil and sediment; thickness of the unsaturated zone; or types of vegetation. All of these influence the soil moisture content and water table datum.

(2) The change in regional groundwater levels is not gradual; rather it is a process of sudden increase due to governmental intervention. Therefore, it is difficult to apply many of the existing models. For example, precipitation is commonly set as an important parameter in many models, but there was no significant change in precipitation that affected the parameters used in this study. Rather, it was administrative measures that caused influential changes in the groundwater levels.

(3) The accuracy of our results requires a quantitative analysis and evaluation of the overdraft effect, as opposed to simply calculating a groundwater recharge rate.

Therefore, the common groundwater recharge analysis model was not appropriate for this study. Instead, a field test was designed to facilitate the development of a new quantitative analysis evaluation system based on the available data. This method considers the precipitation process, crop water requirements, water conservancy facilities construction, crop structure adjustments, and other factors, therefore more effectively assessing the effect of governmental overdraft measures. Moreover, based on this analysis of water-saving data, we can offer the potential for the replication of different overdraft governance measures and provide a useful reference for other groundwater overdraft regions.

\section{Study Area}

Situated in the Heilonggang River basin in the Hebei Province, Hengshui City covers an area of $8815 \mathrm{~km}^{2}$ and has jurisdiction of over 11 counties, 114 towns, and 4994 villages with a total population 
of 4.5 million (Figure 1). Critically short of water, the city possesses water resources of 613 million $\mathrm{m}^{3}$ (148 $\mathrm{m}^{3}$ per capita or $76 \mathrm{~m}^{3}$ per " $\mathrm{mu}$," which is a unit of area in China equal to 0.0667 hectares), whereas the total water consumption reaches 1740 million $\mathrm{m}^{3}$. Due to natural conditions and increasing socioeconomic water demand, Hengshui City depends heavily on reducing the ecological water demand and over-exploiting groundwater (800 to 1000 million $\mathrm{m}^{3}$ per year). The city experienced the first regional groundwater depression cone in the North China Plain, the most excessive pumping of groundwater, and the largest area of water over-exploitation (Figure 2). Following the construction of motor-driven wells in 1969, groundwater overdraft in Hengshui City has occurred for approximately half a century. The ensuing production, lifestyle, and ecological issues can be described as "three drops and one rise," which indicates ground subsidence followed by a decline in the static water level, decreased water output from motor-driven wells, and increased water cost. In summary, ongoing and large-scale groundwater overdraft in Hengshui City has resulted in a sequence of geological disasters and significant impacts on socioeconomic development and environmental protection. The Number 1 Central Document of 2014 clearly asks for "piloting the rehabilitation of agricultural resources" and points out that pilot projects must be carried out for the comprehensive governance of groundwater overdraft funnel areas throughout the North China Plain. Simultaneously, compensation measures must be implemented to guarantee the overall income level of farmers in these areas.

Based on these policies, the Ministry of Finance has worked with the Ministry of Water Resources, Agriculture and Rural Affairs, and Natural Resources to implement comprehensive governance projects for groundwater overdraft in Hebei Province from 2014. Hengshui City was selected as one of the first pilot cities to carry out these governance projects.
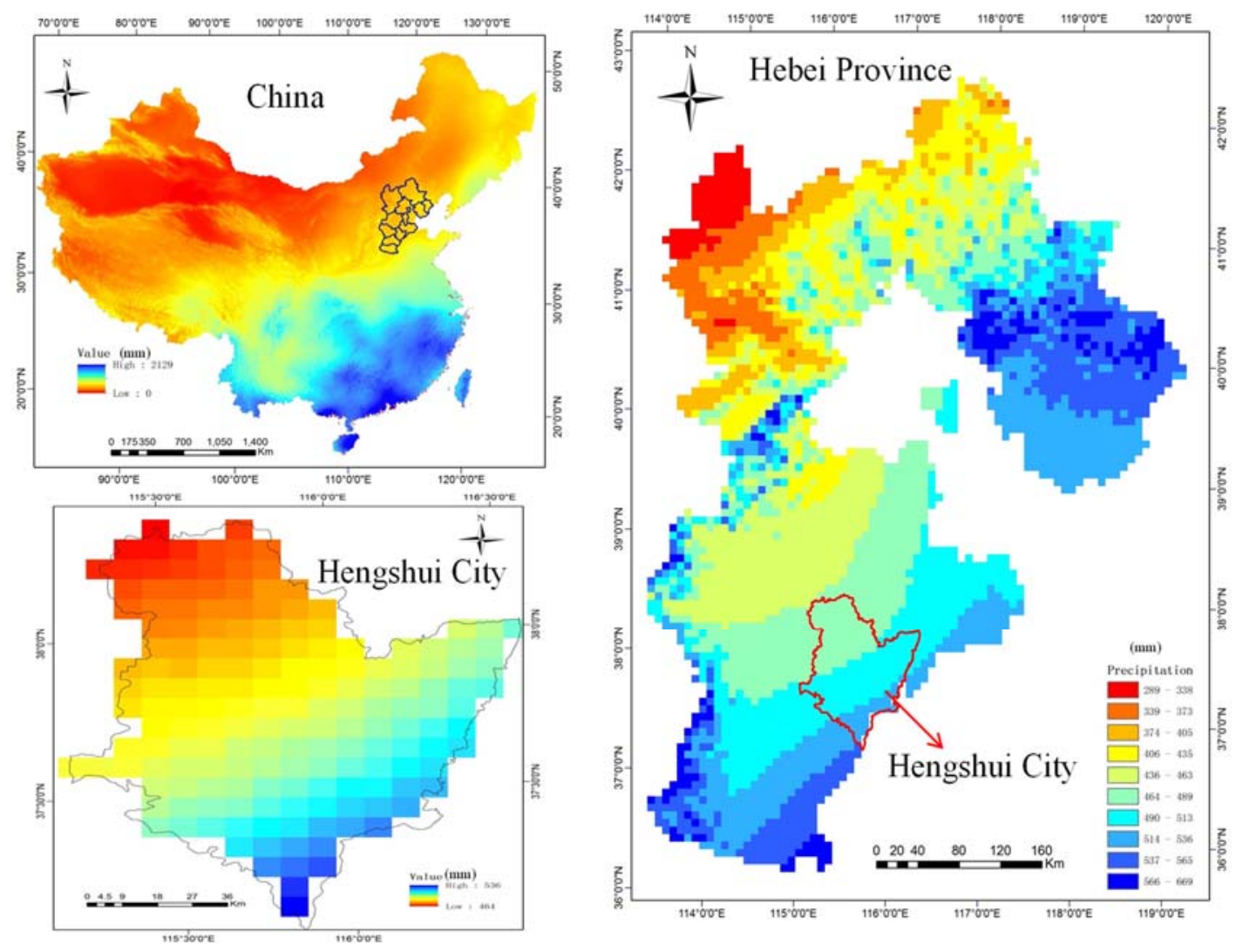

Figure 1. Location of the study area and its annual precipitation (in $\mathrm{mm}$ ). 


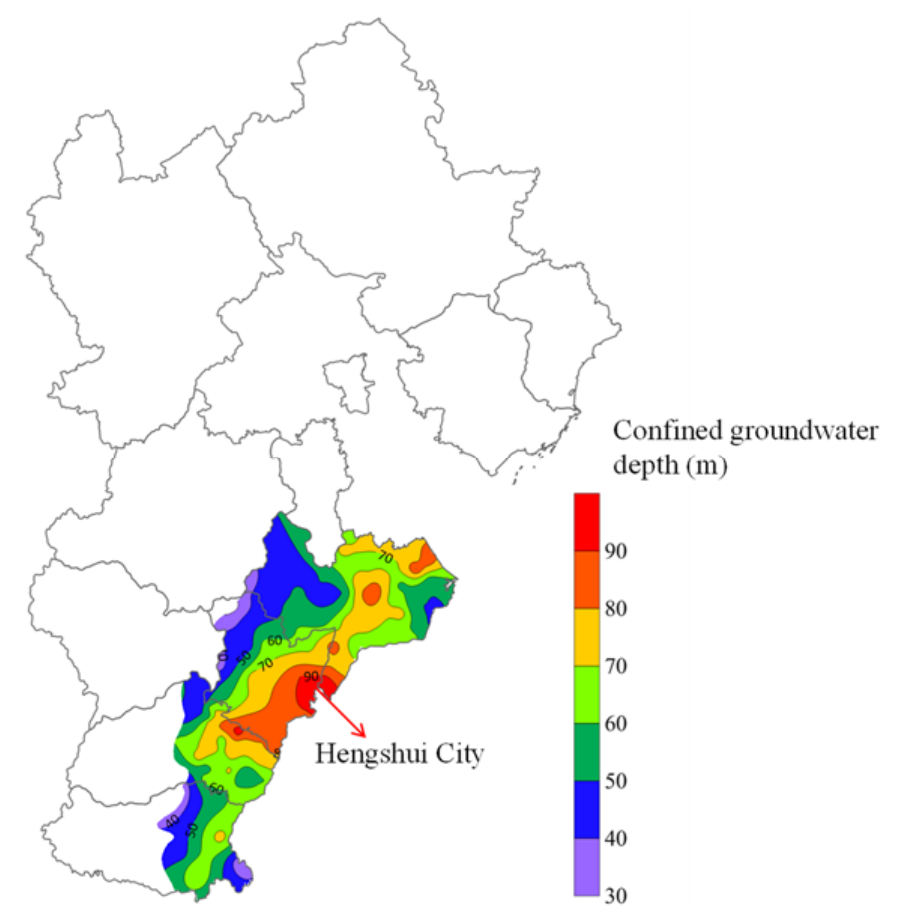

Figure 2. Confined groundwater depth (in $\mathrm{m}$ ) in the study area.

\subsection{Governance Measures}

Pilot areas in Hengshui City cover eleven districts and counties, including Taocheng District, Jizhou City, Shenzhou City, Raoyang County, Wuqiang County, Fucheng County, Wuyi County, Jing County, Zaoqiang County, and Gucheng County. Considering the actual water use conditions of these districts and counties, three water-saving measures were implemented [40]:

(1) Planting structure adjustments and the promotion of agronomy water-saving techniques. In seriously over-exploited areas, planting structure adjustments and agronomy water-saving techniques were applied to $87,000 \mathrm{mu}$ and 1,870,200 mu, respectively. Additionally, 50,000 mu of farming land was converted into non-agricultural crops. These measures aimed to save 115 million $\mathrm{m}^{3}$ of groundwater annually.

(2) Strengthening of hydraulic engineering construction. A series of water conservancy projects from water sources to the field were planned and implemented, including water diversion, extraction, storage, and irrigation projects, to optimize water source structure and effectively use local and external water. The governed irrigation area was $863,200 \mathrm{mu}$ (including $86,800 \mathrm{mu}$ of high-efficiency water-saving irrigation area). These measures were expected to save 69.29 million $\mathrm{m}^{3}$ of groundwater annually.

(3) Innovative management mechanisms. Market methods were combined with government regulation to inspire innovation from the public and improve the comprehensive reform of agricultural water pricing, farmland water rights systems, project operation management, and the adoption of policies and regulations.

\subsection{Expected Goals}

During 2015, planting structure adjustments in pilot areas were expected to decrease groundwater overdraft by 191 million $\mathrm{m}^{3}$. Through the implementation of the over-exploitation governance plan in the South-North Water Transfer Project, the decrease in groundwater overdraft in terms of industrial and domestic consumption was projected to be 70 million $\mathrm{m}^{3}$. The overall reduction target was 261 million $\mathrm{m}^{3}$ (Table 1). The total area of planting structure adjustments and agronomy water-saving techniques was 2.007 million mu (Table 2). 
Table 1. Expected outcomes of groundwater overdraft governance for Hengshui City in 2015.

\begin{tabular}{|c|c|}
\hline Strategy & $\begin{array}{l}\text { Water-Saving } \\
\left(100 \text { Million }^{3}\right)\end{array}$ \\
\hline $\begin{array}{c}\text { Adjusting planting structure and promoting agronomy } \\
\text { water-saving techniques }\end{array}$ & 1.15 \\
\hline High-efficiency use of groundwater & 0.07 \\
\hline High-efficiency use of surface water & 0.37 \\
\hline High-efficiency use of external water & 0.20 \\
\hline High-efficiency use of slightly brackish water & 0.06 \\
\hline Water-saving through management & 0.06 \\
\hline Sub-total; agricultural water overdraft governance goal & 1.91 \\
\hline Additional urban overdraft governance goal & 0.70 \\
\hline Total water-saving goal & 2.61 \\
\hline
\end{tabular}

Table 2. Details of planting structure adjustments and agronomy water-saving techniques.

\begin{tabular}{cc}
\hline Strategy & Application Area (10,000 $\mathbf{~ m u})$ \\
\hline Planting pattern adjustment & 8.7 \\
Non-agricultural crops replacement & 5.0 \\
Water-saving during spring irrigation of wheat & 174 \\
Conservation tillage & 10.3 \\
Integration of water and fertilizer & 2.72 \\
\hline Total & 200.7 \\
\hline
\end{tabular}

Hebei Province proposed that by 2017, with the exception of domestic use, the exploitation of deep confined water must be abolished in surface water coverage areas and fallow lands. Furthermore, by 2020, groundwater extraction and recharge processes should be balanced, such that the central water levels in groundwater funnel regions should experience a significant increase. Simultaneously, there should be significant improvements to the ecological environment of the groundwater system.

As listed in Table 1, Hengshui City has adopted seven strategies for groundwater overdraft treatment, with a list of the expected outcome for each strategy. We can observe that the strategy that has saved the largest amount of water is the adjusting planting structure and promoting agronomy water-saving techniques. The actual implementation can be divided into five specific strategies, as listed in Table 2, where the application area for each strategy is clarified.

The high-efficiency use of groundwater, surface water, external water, and slightly brackish water refers to dredging and connecting rivers, constructing high-standard pipe irrigation systems in fields, and prohibiting groundwater exploitation in restricted areas to optimize the water resources structure and reduce the waste of water resources during transportation and storage. Water-saving via management mainly adopts a ladder water price policy to strengthen the water fee collection, thus avoiding waste. Additional urban overdraft governance indicates the use of a South-to-North water diversion and other external water resources to replace the collection of urban water from groundwater.

\subsection{Data Sources}

Data were collected via reference materials, field surveys, and well testing. Data include field test results in terms of water output per $\mathrm{kWh}$ at 79 single wells, groundwater levels in each region, precipitation data from 10 meteorological stations, 2016 planting structure data, monthly electricity consumption data at all irrigation wells during 2016, annual power consumption for agricultural irrigation since 2011, and project plans and their outcomes in pilot districts and counties. These data were provided by the water resources bureau of Hengshui City, except for the field test data.

\section{Methodology}

Governance projects commenced in 2014 and finished in 2015. Hence, 2013 and 2016 were selected as the pre-governance and assessment years, respectively. By comparing data from these two years, the performance of the governance measures was evaluated. 


\subsection{Estimation of Agricultural Groundwater Consumption}

In the study region, agricultural producers have the highest demand for groundwater resources. Precisely measuring the agricultural groundwater consumption is difficult because motor-driven wells, which supply water, are generally managed by individual farmers or villages who may not be aware of the need to install measurement systems that record water use behaviors. Furthermore, irrigation demand determines groundwater exploitation, which is, in turn, influenced by the interannual variability and seasonal distribution of precipitation. During high (or low) precipitation years, there is a decrease (or increase) in groundwater exploitation. Consequently, to accurately compare pre-governance and assessment years, we must account for precipitation differences using a conversion calculation to determine the actual groundwater exploitation.

\subsubsection{Determining Actual Exploitation}

Groundwater used in agricultural activities is obtained via motor-driven wells, which are generally not equipped with facilities to measure the extraction volume. However, the electric power consumption of each well can be obtained, which can be used to evaluate the yield of the motor-driven wells via historical power consumption data multiplied by the water output per $\mathrm{kWh}$. Power consumption data were collected via survey and water output per kWh obtained during field testing. For a single agricultural well, the water output can be obtained by measuring its output and power consumption over time. Then, historical output can be calculated by multiplying the output per $\mathrm{kWh}$ with historical power consumption data.

This method is accurate when the number of agricultural wells is small. However, there are typically tens of thousands of agricultural wells in each pilot county, such that it is infeasible to conduct field experiments at each well. In this case, the "point-to-plane method" was utilized. The "point" refers to a typical field and all agricultural wells within the field, while "plane" refers to the planting structure and acreage of a county. Pilot areas were classified and divided into typical regions (Figure 3) according to the growing schedule of the main crops. Then, experiments on water output from each well were used to calculate the total groundwater exploitation of the region using power consumption data. Water output per unit area of the main crop was evaluated by dividing the total exploitation by the planting area of the region. Finally, the water output per unit area of each major crop type was applied to the entire pilot district to determine the total agricultural groundwater yield. The equations are discussed in the following sections.

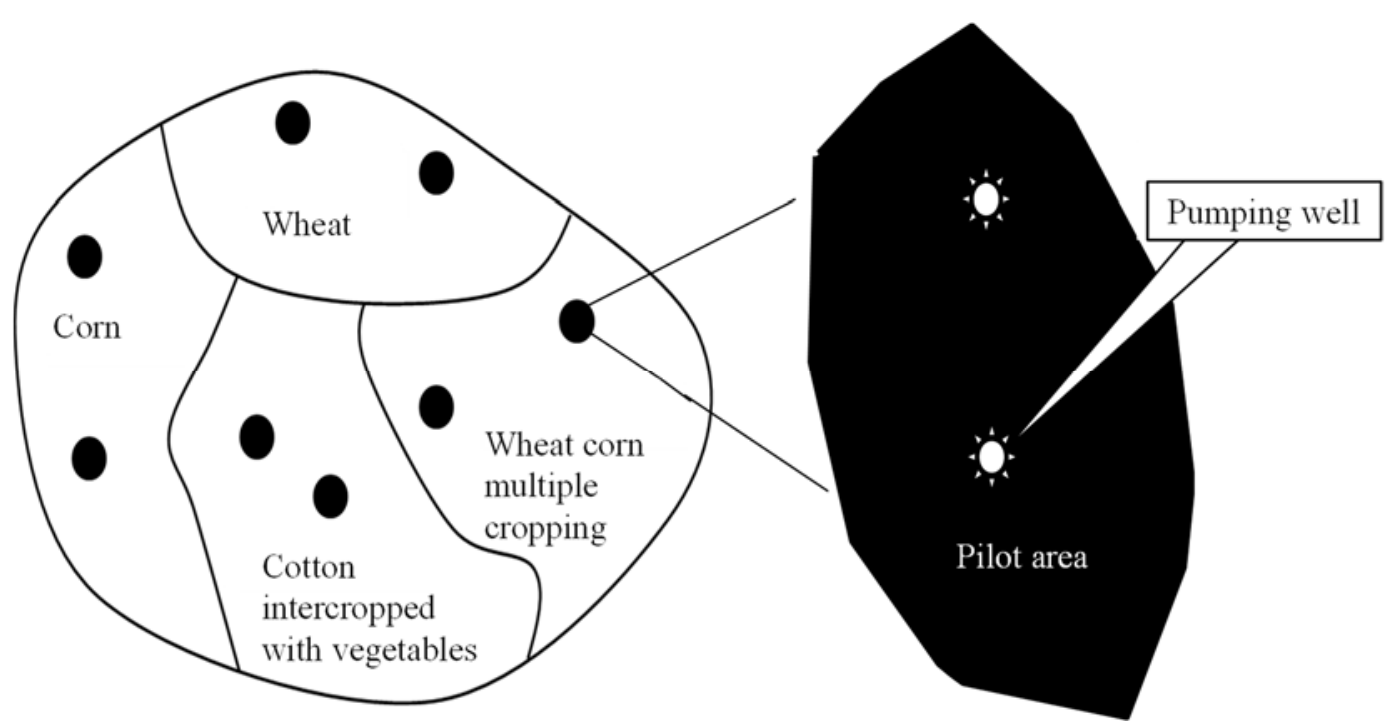

Figure 3. Schematic showing the cropping structure and typical region division in pilot areas. 


\subsubsection{Accounting for Precipitation}

(1) Effective precipitation and actual exploitation

Agricultural water demand is impacted by total precipitation and its annual distribution. Different crops can obtain different effective precipitation rates even with the same annual precipitation distribution. Effective precipitation refers to the amount of precipitation required for the evapotranspiration of a crop during its growth period and is related to crop water demand and the annual distribution of rainfall. For a specific crop, rainfall that can be absorbed is different under different annual rainfall distributions, even with the same annual precipitation (Figure 4). The water demand for crops not satisfied by effective precipitation is met by agricultural irrigation activities, indicating that there is a correlation between the effective precipitation and groundwater exploitation. Thus, depicting the relationship between effective precipitation and agricultural groundwater exploitation helps reflect the variation in agricultural groundwater exploitation with the effective precipitation.

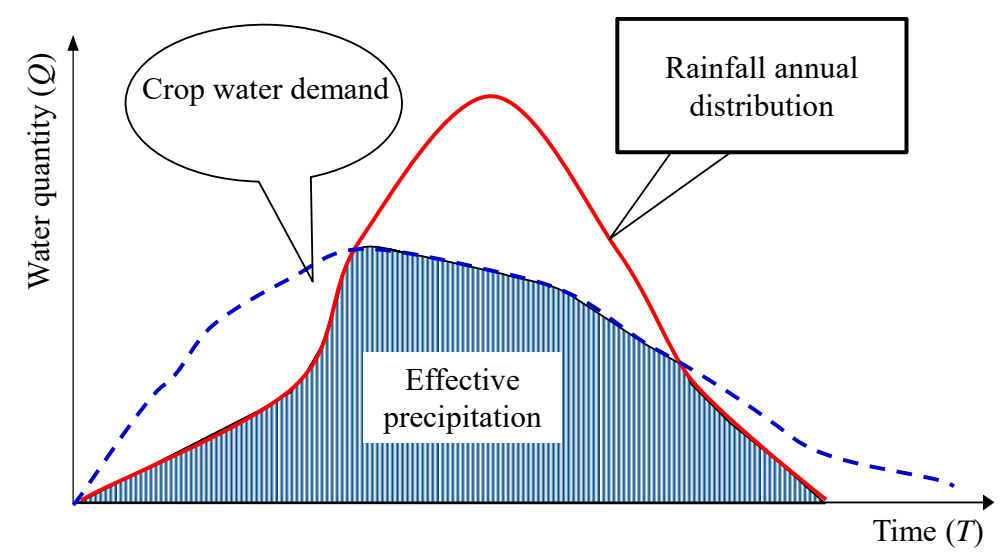

Figure 4. Comparison of the annual rainfall distribution and crop water demand highlighting the effective precipitation.

Effective precipitation is related to crop water demand. Therefore, the daily crop water demand $\left(E T_{c} ; \mathrm{mm} / \mathrm{d}\right)$ should be determined using the crop coefficient approach:

$$
E T_{c}=K_{c} E T_{0}
$$

where $E T_{0}$ is the reference crop evapotranspiration in $\mathrm{mm} / \mathrm{d}$. The crop coefficient, $K_{c}$, is calculated using the time-averaged crop coefficient approach recommended by the Food and Agriculture Organization of the United Nations [41], which generalizes changes in the crop coefficient during the growth period into four stages and uses three crop coefficients, known as $K_{C i n i}, K_{C m i d}$, and $K_{C e n d}$, to represent the stages. The reference crop evapotranspiration, $E T_{0}$, can be calculated using Equation (2) with daily weather data [42], including the daily maximum and minimum temperature, average temperature, wind speed, humidity, and sunshine duration as follows:

$$
E T_{0}=\frac{0.408 \Delta\left(R_{n}-G\right)+r \frac{900}{T+273} u_{2}\left(e_{s}-e_{a}\right)}{\Delta+\left(1+0.34 u_{2}\right)}
$$

where $R_{n}$ is the net radiation in $\mathrm{MJ} /\left(\mathrm{m}^{2} \mathrm{~d}\right) ; G$ is the soil heat flux in $\mathrm{MJ} /\left(\mathrm{m}^{2} \cdot \mathrm{d}\right) ; \mathrm{T}$ is the daily average temperature in ${ }^{\circ} \mathrm{C}$; $e_{s}$ is the saturation vapor pressure in $\mathrm{kPa}$; $e_{a}$ is the actual vapor pressure in $\mathrm{kPa} ; \Delta$ is the slope of the saturation vapor pressure function at temperature $\mathrm{T} \mathrm{in} \mathrm{kpa} /{ }^{\circ} \mathrm{C} ; \mathrm{r}$ is the hygrometer constant in $\mathrm{kpa} /{ }^{\circ} \mathrm{C}$; and $u_{2}$ is the average $2 \mathrm{~m}$ wind speed in $\mathrm{m} \mathrm{s}^{-1}$.

Rainfall can be stored in the soil and a large amount of rainfall on a single day can be absorbed by crops in the following days, indicating that effective precipitation should be considered over time 
intervals. Using available literature and a fitting test, the fitted curve between the effective precipitation measured over a ten-day period and agricultural groundwater exploitation was the most appropriate for the pilot areas of Hebei Province. Therefore, the effective precipitation in this study employed a ten-day scale as follows:

$$
\left\{\begin{array}{c}
E P_{d}=E T_{C^{\prime}}^{d} \quad P_{d}>E T_{C}^{d} \\
E P_{d}=P_{d}, \quad P_{d} \leq E T_{C}^{d}
\end{array}\right.
$$

where $E P_{d}$ is the effective precipitation within a ten-day period in $\mathrm{mm} ; E T_{c}^{d}$ is the ten-day water demand of the crop in $\mathrm{mm}$; and $P_{d}$ is the ten-day precipitation in $\mathrm{mm}$.

The effective precipitation during the entire crop growth period can be defined as the sum of the ten-day effective precipitation:

$$
E P=\sum E P_{d}
$$

For a pilot area (county, city, or district), the effective precipitation for one specific year can be defined as the weighted average of the effective precipitation for each crop in the irrigation district according to the planting area of each crop type as follows:

$$
E P_{c}=\frac{\sum E P_{i} \cdot A_{i}}{\sum A_{i}}
$$

where $E P_{c}$ is the annual effective precipitation of the pilot area; $E P_{i}$ is the effective precipitation of the $i$ th crop during its growth period; and $A_{i}$ is the well irrigation area of the $i$ th crop in mu.

Based on the planting structure of the pilot areas in 2013, a time series of effective precipitation from 1956 to 2013 was calculated and ranked, such that the curve of effective precipitation and frequency was fitted to a Pearson III curve [43]. The fitted curve was then used to determine the effective precipitation when the effective rainfall frequency was $25 \%, 50 \%$, and $75 \%$, defined as $P_{25}, P_{50}$, and $P_{75}$, respectively.

Using the effective precipitation series for the past ten years (2004-2013), we defined those years, whose effective precipitation was closest to $P_{25}, P_{50}$, and $P_{75}$, as the representative years of high, normal, and low precipitation, respectively. The effective precipitation of these representative years was then defined as $P_{h}, P_{n}$, and $P_{l}$.

The actual groundwater exploitation of the representative years can be evaluated using these methods. For a district, the groundwater exploitation of the high, normal, and low precipitation years during the 2013 base year and actual exploitation during that year are as follows:

$$
\begin{gathered}
W_{h}=\sum\left(w_{i}^{h} \cdot \mathrm{a}_{i}^{2013}\right) ; W_{n}=\sum\left(w_{i}{ }^{n} \cdot \mathrm{a}_{i}^{2013}\right) \\
W_{l}=\sum\left(w_{i}^{l} \cdot \mathrm{a}_{i}^{2013}\right) ; W_{2013}^{a c}=\sum\left(w_{\mathrm{i}}^{2013} \cdot \mathrm{a}_{i}^{2013}\right),
\end{gathered}
$$

where $a_{i}^{2013}$ is the well irrigation area of the $i$ th crop in 2013 in 10,000 mu; $w_{i}^{h}, w_{i}^{n}, w_{i^{\prime}}^{l}$ and $w_{i}^{2013}$ are the exploitations per unit area of the $i$ th crop during the high, normal, and low precipitation years and 2013 in $\mathrm{m}^{3} / \mathrm{mu}$, respectively; and $W_{2013}^{a c}$ is the actual exploitation during the pre-governance base year (2013). Based on this data, the precipitation-water $\mathrm{P}(\mathrm{P}-\mathrm{W})$ relationship curve can be fitted using the power function curve based on four points, i.e., $\left(P_{h}, W_{h}\right),\left(P_{n}, W_{h}\right),\left(P_{l}, W_{l}\right)$, and $\left(P_{2013}, W_{2013}^{a c}\right)$, as shown in Figure 5. 


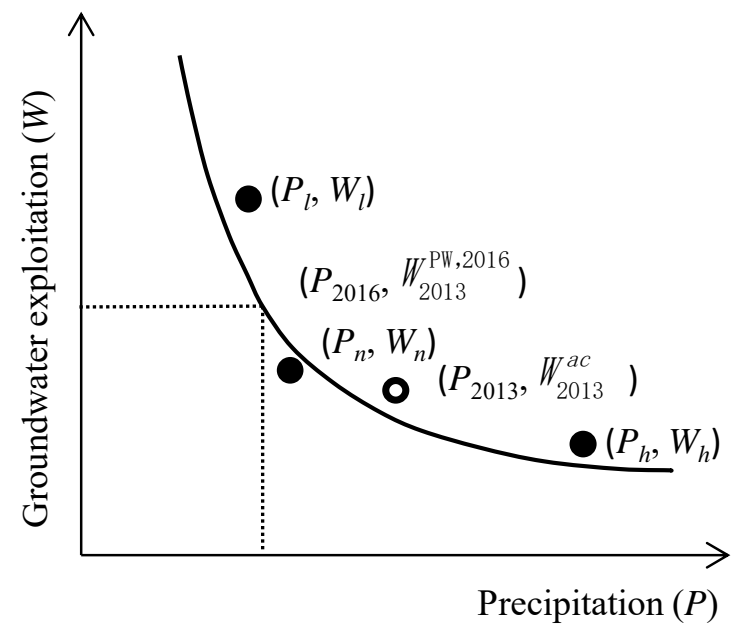

Figure 5. The Precipitation-Water (P-W) relationship curve in the pre-governance base year (2013).

(2) Exploitation of the pre-governance base year under normal precipitation conditions

Groundwater exploitation for the pre-governance base year under normal precipitation conditions was determined by interpolation of the $\mathrm{P}-\mathrm{W}$ relationship curve. The corresponding groundwater exploitation value on the $\mathrm{P}-\mathrm{W}$ relationship curve was found using the effective precipitation value of the district in normal precipitation years. This value is the groundwater exploitation of the pre-governance base year (2013) under normal precipitation conditions and is marked as $W_{2013}^{n}$ in this study.

(3) Exploitation of the assessment base year under normal precipitation conditions

The actual exploitation of the assessment base year is as follows:

$$
W_{2016}^{a c}=\sum\left(w_{\mathrm{i}}^{2016} \cdot \mathrm{a}_{i}^{2016}\right),
$$

where $W_{2016}^{a c}$ is the actual groundwater exploitation during 2016 in $10,000 \mathrm{~m}^{3} ; w_{i}^{2016}$ is the exploitation per unit area of the $i$ th crop during 2016 in $\mathrm{m}^{3} / \mathrm{mu}$; and $a_{i}^{2016}$ is the well irrigation area of the $i$ th crop during 2016 in 10,000 mu.

Groundwater exploitation of the assessment base year under normal precipitation conditions was measured using the groundwater exploitation during the pre-governance base year under normal precipitation conditions, the actual exploitation during the assessment base year, annual precipitation during the assessment base year, and the $\mathrm{P}-\mathrm{W}$ relationship curve are as follows:

$$
\frac{W_{2016}^{n}}{W_{2016}^{a c}}=\frac{W_{2013}^{n}}{W_{2013}^{\mathrm{PW}, 2016}}
$$

where $W_{2016}^{n}$ is the exploitation of the assessment base year under normal precipitation conditions in $10,000 \mathrm{~m}^{3}$ and $W_{2013}^{P W, 2016}$ is the corresponding exploitation value of the precipitation for the assessment base year from the $\mathrm{P}-\mathrm{W}$ relationship curve in $10,000 \mathrm{~m}^{3}$ (Figure 5; note: $P_{2016}$ is the annual precipitation of the year 2016). The theoretical basis for the conversion calculation is that, for a certain district, the ratio of groundwater exploitation during years with similar precipitation to groundwater exploitation during normal precipitation years is relatively stable.

Equation (8) can be transformed into:

$$
W_{2016}^{n}=\frac{W_{2013}^{n}}{W_{2013}^{\mathrm{PW}, 2016}} \times W_{2016}^{a c}=K \times W_{2016^{\prime}}^{a c}
$$


where $K=\frac{W_{2013}^{n}}{W_{2013}^{\mathrm{PW}, 2016}}$ is also defined as the conversion coefficient.

(4) Assessment of groundwater overdraft governance during the base year

The overdraft governance result of the assessment base year is the difference between the exploitation of the pre-governance base year under normal precipitation conditions and that of the assessment base year under normal precipitation conditions:

$$
W_{2016}^{o v}=W_{2013}^{n}-W_{2016}^{n}
$$

where $W_{2016}^{o v}$ is the overdraft governance result of the assessment base year in 10,000 $\mathrm{m}^{3}$.

\subsection{Assessment of Industrial and Domestic Groundwater Overdraft Governance}

Unlike agricultural groundwater consumption, the ratio of groundwater consumption for industrial and domestic use to the total groundwater exploitation is small. There is also a relative centralization of the water supply. Groundwater for urban cities is mainly supplied from a networked system with accurate measuring facilities. Furthermore, the groundwater demand process in urban regions is relatively stable and not influenced by rainfall frequency. Consequently, industrial and domestic groundwater consumption directly derives from monitoring data from the pre-governance and assessment base years without the need for conversion.

\section{Results}

\subsection{Implementation of Overdraft Governance Measures}

Table 3 lists the outcomes of the overdraft governance measures during 2015. These results show that the expected goals have generally been achieved. The total expected area of agricultural overdraft governance measures is 2.007 million mu while the actual area is 2.0068 million $\mathrm{mu}$, with a completion ratio of $99.99 \%$.

Table 3. Implementation conditions of agricultural overdraft governance measures.

\begin{tabular}{cccc}
\hline $\begin{array}{c}\text { Adjusting Cropping Structure and Promoting } \\
\text { Agronomy Water-Saving Techniques }\end{array}$ & $\begin{array}{c}\text { Expected Area } \\
\mathbf{( 1 0 , 0 0 0 ~} \mathbf{~ u})\end{array}$ & $\begin{array}{c}\text { Actual Area } \\
(\mathbf{1 0 , 0 0 0} \mathbf{~ m u})\end{array}$ & $\begin{array}{c}\text { Ratio } \\
\mathbf{( \% )}\end{array}$ \\
\hline Planting pattern adjustment & 8.7 & 8.76 & 100.70 \\
Non-agricultural crops replacement & 5 & 5 & 100 \\
Water-saving during spring irrigation of wheat & 174 & 174 & 100 \\
Conservation tillage & 10.3 & 10.3 & 100 \\
Integration of water and fertilizer & 2.72 & 2,62 & 100 \\
\hline Total & 200.7 & 200.68 & 99.99 \\
\hline
\end{tabular}

Surface water irrigation projects were mainly comprised of the South-to-North Water Diversion Project and the surface water irrigation project in the Shijin Irrigation District, including the construction of the canal system, field projects, and water storage projects for pits and ponds. The actual governance area for this method was $692,100 \mathrm{mu}$ and the completion ratio reached $100.35 \%$. The scale of high-efficiency water-saving construction projects in well irrigation districts was $75,600 \mathrm{mu}$. The planned governance result was $5,673,300 \mathrm{~m}^{3}$, where $100 \%$ of this goal was achieved.

\subsection{Accounting and Conversion Calculation of Actual Agricultural Groundwater Consumption}

A total of 79 agricultural motor-driven irrigation wells in 11 counties and districts of Hengshui City were selected for a monthly power consumption analysis, including 64 confined water wells and 15 unconfined water wells (Figure 6). In the process of selecting the experimental wells, we focused on the existing and working wells with stable crops and reliable electricity consumption data in the 
past ten years, covering as many areas as possible where groundwater overdraft measures were taken. Confined and unconfined water wells were selected respectively to observe the influence that depth has on single-well output per kWh.

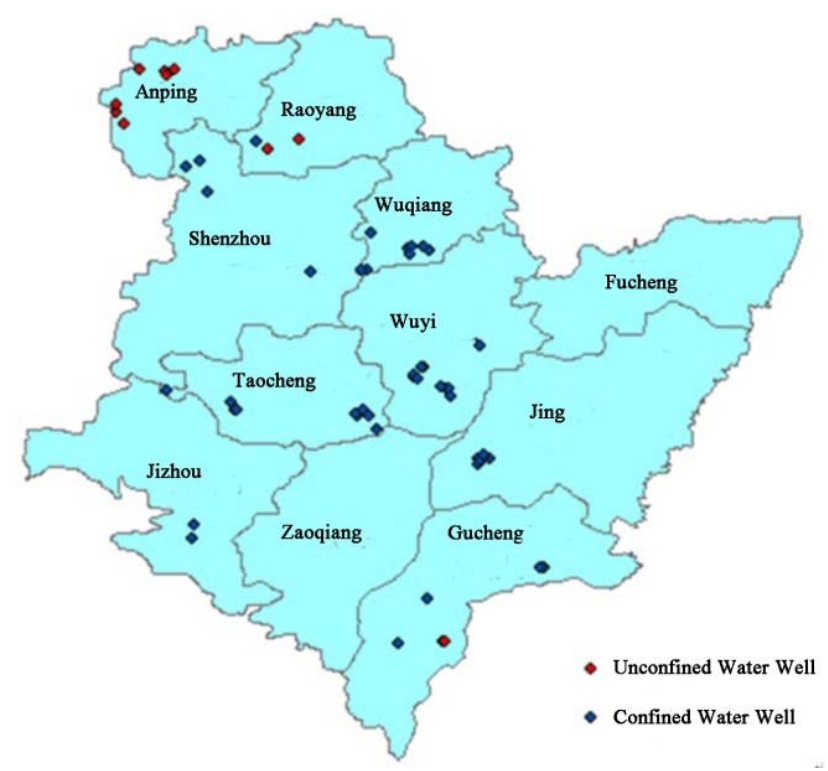

Figure 6. The distribution of wells used in single-well output experiments.

Figure 7 shows the fitted results of the measured values. Groundwater depth is an influential factor that determines the output efficiency of the irrigation wells as output per kWh decreases with groundwater depth. Based on irrigation well output data and crop type, Table 4 lists the average groundwater consumption per mu in Taocheng District. The results of the other areas are not listed in detail. Specifically, the total water consumption during the growing season of a crop in a typical area can be obtained using the measured amount of groundwater extraction per $\mathrm{kWh}$ in a single well and data for irrigation electricity consumption in a typical area, which is then divided by the planting area of such crops in the typical area, such that we can obtain the water consumption per mu of each crop in the typical area. It should be noted here that the irrigation data for each crop refers to the consumption of electricity during the growth period. For example, the consumption of electricity for corn refers to the consumption of electricity from July to September.
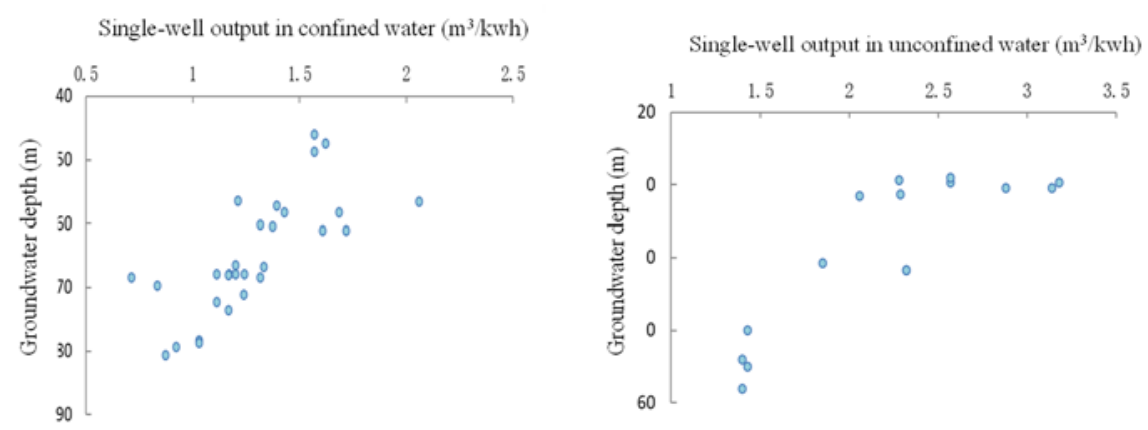

Figure 7. Relationship between single-well output and groundwater depth. 
Table 4. Groundwater consumption per mu for major crops in Taocheng District $\left(\mathrm{m}^{3}\right)$.

\begin{tabular}{|c|c|c|c|c|}
\hline No. & Measures & Crops & Area $(\mathrm{mu})$ & $\begin{array}{l}\text { Consumption } \\
\text { Per } \mathrm{mu}\left(\mathrm{m}^{3}\right)\end{array}$ \\
\hline 1 & High-efficiency water-saving & Red beans (interplanting) & 267.2 & 141 \\
\hline 2 & High-efficiency water-saving & Millet & 267.2 & 122 \\
\hline 3 & High-efficiency water-saving & Barley grass & 1235 & 137 \\
\hline 4 & Replacement by surface water & Wheat & 21,450 & 81 \\
\hline 5 & Replacement by surface water & Corn & 21,450 & 30 \\
\hline 6 & Replacement by surface water & Cotton & 11,550 & 58 \\
\hline 7 & Adjusting cropping structure & Corn & 20,000 & 53 \\
\hline 8 & Conservation tillage & Wheat & 10,000 & 112 \\
\hline 9 & Conservation tillage & Corn & 10,000 & 42 \\
\hline 10 & $\begin{array}{l}\text { Integration of water and } \\
\text { fertilizer-wheat and corn }\end{array}$ & Wheat & 1500 & 123 \\
\hline 11 & $\begin{array}{l}\text { Integration of water and } \\
\text { fertilizer-wheat and corn }\end{array}$ & Corn & 1500 & 29 \\
\hline 12 & $\begin{array}{l}\text { Integration of water and } \\
\text { fertilizer-vegetable }\end{array}$ & Vegetable & 1000 & 246 \\
\hline 13 & $\begin{array}{l}\text { Non-agricultural crops } \\
\text { replacement }\end{array}$ & Ecological forest & 14,000 & 45 \\
\hline
\end{tabular}

\subsection{Overdraft Governance Performance}

The actual groundwater exploitation in Hengshui City during the pre-governance base year was 532.10 million $\mathrm{m}^{3}$ while the actual exploitation during the assessment base year was 418.18 million $\mathrm{m}^{3}$, a decrease of 113.92 million $\mathrm{m}^{3}$. Groundwater exploitation under normal precipitation conditions was 646.14 and 458.19 million $\mathrm{m}^{3}$ during 2013 and 2016, respectively. Overdraft governance measures saved 187.95 million $\mathrm{m}^{3}$, including 100.84 million $\mathrm{m}^{3}(53.7 \%)$ in agriculture, 78.45 million $\mathrm{m}^{3}(41.7 \%)$ in hydraulic projects, and 8.66 million $\mathrm{m}^{3}(4.6 \%)$ in forestry projects (Tables 5 and 6 ).

Table 5. Accounting and conversion calculation results for groundwater in 2013 and 2016.

\begin{tabular}{cccc}
\hline Year & $\begin{array}{c}\text { Actual Consumption } \\
\left(\mathbf{1 0 , 0 0 0} \mathbf{~ m}^{\mathbf{3}}\right)\end{array}$ & $\begin{array}{c}\text { Consumption Under } \\
\text { Normal Precipitation } \\
\left(\mathbf{1 0 , 0 0 0} \mathbf{~ m}^{\mathbf{3}}\right)\end{array}$ & $\begin{array}{c}\text { Overdraft Governance } \\
\text { Capacity } \\
\left(\mathbf{1 0 , 0 0 0} \mathbf{~ m}^{\mathbf{3}}\right)\end{array}$ \\
\hline 2013 & 53,210 & 64,614 & 18,795 \\
2016 & 41,818 & 45,819 & \\
\hline
\end{tabular}

Table 6. Overdraft governance performance of the pilot project areas in Hengshui City.

\begin{tabular}{|c|c|c|c|c|}
\hline Project Type & $\begin{array}{c}\text { Governance } \\
\text { Capacity } \\
\left(10,000 \mathrm{~m}^{3}\right)\end{array}$ & $\begin{array}{c}\text { Implementation } \\
\text { Area } \\
(10,000 \mathrm{mu})\end{array}$ & $\begin{array}{l}\text { Governance } \\
\text { Capacity } \\
\text { Per mu }\left(\mathrm{m}^{3}\right)\end{array}$ & $\begin{array}{c}\text { Ratio } \\
(\%)\end{array}$ \\
\hline Planting pattern adjustment & 1508.61 & 8.76 & 177.2 & 8.03 \\
\hline $\begin{array}{l}\text { Water-savings during spring } \\
\text { irrigation of wheat }\end{array}$ & 7897.85 & 173.979 & 46.7 & 42.02 \\
\hline Conservation tillage & 442.28 & 10.3 & 44.2 & 2.35 \\
\hline $\begin{array}{l}\text { Integration of water and } \\
\text { fertilizer-wheat and corn }\end{array}$ & 96.72 & 1.8 & 55.3 & 0.51 \\
\hline $\begin{array}{l}\text { Integration of water and } \\
\text { fertilizer-vegetable }\end{array}$ & 139.68 & 0.82 & 175.2 & 0.74 \\
\hline $\begin{array}{l}\text { Non-agricultural crops } \\
\text { replacement (forestry) }\end{array}$ & 865.50 & 5 & 178.1 & 4.61 \\
\hline Replacement by surface water & 7319.36 & 69.21 & 73.8 & 38.95 \\
\hline Groundwater irrigation project & 525 & 7.545 & 71.6 & 2.79 \\
\hline Totals & 18,795 & 277.41 & 67.7 & 100.00 \\
\hline
\end{tabular}


One goal of the Hebei Province comprehensive overdraft governance was to supply the industrial and domestic water demand of Hengshui City using the Project of South Water to North, contributing 70 million $\mathrm{m}^{3}$ to the overdraft governance target. However, project delays meant that only the Zaoqiang and Shenzhou districts ( 23.92 million $\mathrm{m}^{3}$ and $68,000 \mathrm{~m}^{3}$, respectively) were able to use the water from the project to satisfy industrial and domestic water consumption. Hence, overdraft governance resulted in an industrial and domestic groundwater savings of only 23.99 million $\mathrm{m}^{3}$.

As listed in Table 6, according to the data on the governance capacity per mu, the three overdraft governance measures with the highest efficiency were (1) non-agricultural crops replacement (forestry), (2) planting pattern adjustments, and (3) the integration of water and fertilizer-vegetable. The amount of groundwater saved per mu is the largest of these measures, which can be considered and promoted in future measures. However, considering the area and total governance capacity, spring irrigation of wheat and replacement by surface water are the two most important water-saving measures, which are required to further strengthen the management and implementation effect.

The overdraft governance target of Hengshui City for agriculture was 191 million $\mathrm{m}^{3}$. Actual savings were 187.95 million $\mathrm{m}^{3}, 98.4 \%$ of the expected outcome. Furthermore, the governance target for industrial and domestic consumption was 70 million $\mathrm{m}^{3}$. Actual savings were 23.99 million $\mathrm{m}^{3}$, $34.3 \%$ of the expected target.

\subsection{Change in Confined Groundwater Levels}

The impact that overdraft governance has on groundwater levels can be determined by measuring the depth of confined groundwater in each county. Table 7 lists the groundwater depth and corresponding changes for nine counties at the end of 2014, 2015, and 2016. Groundwater levels in most counties have risen based on Table 7 . The cumulative average variation in groundwater depth in Hengshui City for this time period was $-8.37 \mathrm{~m}$.

Table 7. Depth of confined groundwater in Hengshui City during 2014, 2015, and 2016 (m).

\begin{tabular}{|c|c|c|c|c|c|c|c|}
\hline County & $\begin{array}{l}\text { December } \\
2014(\mathrm{~m})\end{array}$ & $\begin{array}{c}\text { December } \\
2015(\mathrm{~m})\end{array}$ & $\begin{array}{l}\text { Variation } \\
\quad(\mathrm{m})\end{array}$ & $\begin{array}{l}\text { December } \\
2015(\mathrm{~m})\end{array}$ & $\begin{array}{l}\text { December } \\
2016(\mathrm{~m})\end{array}$ & $\begin{array}{l}\text { Variation } \\
\text { (m) }\end{array}$ & $\begin{array}{c}\text { Cumulative } \\
\text { Variation } \\
(2014-2016)(\mathrm{m})\end{array}$ \\
\hline Raoyang & 46.45 & 42.67 & -3.78 & 42.67 & 41.84 & -0.83 & -4.61 \\
\hline Shenzhou & 51.47 & 50.23 & -1.24 & 50.23 & 49.9 & -0.33 & -1.57 \\
\hline Wuyi & 86.72 & 77.96 & -8.76 & 77.96 & 71.67 & -6.29 & -15.05 \\
\hline Taocheng & 76.88 & 72.21 & -4.67 & 72.21 & 68.45 & -3.76 & -8.43 \\
\hline Fucheng & 80.8 & 69.83 & -10.97 & 69.83 & 70.55 & 0.72 & -10.25 \\
\hline Jing & 89.2 & 87.33 & -1.87 & 87.33 & 86.18 & -1.15 & -3.02 \\
\hline Jizhou & 73.43 & 75.22 & 1.79 & 75.22 & 68.59 & -6.63 & -4.84 \\
\hline Zaogiang & 85.9 & 83.66 & -2.24 & 83.66 & 82.4 & -1.26 & -3.5 \\
\hline Gucheng & 85.37 & 86.23 & 0.86 & 86.23 & 86.43 & 0.2 & 1.06 \\
\hline $\begin{array}{c}\text { Hengshui City } \\
\text { Average }\end{array}$ & 83.66 & 80.21 & -3.45 & 80.21 & 75.29 & -4.92 & -8.37 \\
\hline
\end{tabular}

Notes: negative (or positive) values represent the rebound (or decline) in the groundwater levels.

\subsection{Major Factors Affecting Overdraft Governance Performance}

The average annual precipitation in Hengshui City between 1965 and 2013 was 485 mm. During the main wheat irrigation period (March to May), the average precipitation is $62 \mathrm{~mm}$. By contrast, during the corn irrigation period (June to September), which is also the flood season, the average precipitation is $378 \mathrm{~mm}$. During 2013, the annual precipitation $(632 \mathrm{~mm})$ was markedly higher as compared to the historical average, such that we consider that this was a wet year. The annual precipitation in 2015 and 2016 was 531 and $536 \mathrm{~mm}$, respectively, both of which are considered to be normal-wet years. These rainfall characteristics were beneficial to the restoration of groundwater levels in 2016. 
During 2016, Hengshui City planned to replace 61.80 million $\mathrm{m}^{3}$ of groundwater using surface water for agricultural irrigation. However, the actual diverted volume of surface water used in agriculture was much higher ( 258.31 million $\mathrm{m}^{3}$ ). This surface water provided significant support in realizing the overdraft governance target. Furthermore, an estimated 70 million $\mathrm{m}^{3}$ of water from the South-to-North Water Diversion Project was used for urban overdraft governance. However, project delays meant that only 23.99 million $\mathrm{m}^{3}$ of water was drawn from the South-to-North Water Diversion Project, adversely impacting the achievement of the urban overdraft governance target.

Crop planting structure is impacted by fluctuations in agricultural product market prices, especially in non-pilot areas. In recent years, the market prices of wheat and corn have increased while the price of cotton, a drought-tolerant crop with small irrigation demands, has declined sharply. Consequently, farmers have switched their interests to wheat and corn, which have higher irrigation demands. During 2016, the planting area of cotton in the pilot areas of Hengshui City was reduced by 770,000 mu, a decline of $80,000 \mathrm{mu}$ as compared to 2015 . This shift resulted in intense pressure on agricultural irrigation. Despite all the water-saving measures introduced in the pilot regions, shifts in the crop planting structure still imparted a negative influence on groundwater overdraft.

\section{Discussion and Conclusions}

The long-term use of ecological water and groundwater over-exploitation is necessary in Hengshui City to ensure ongoing socioeconomic development. To optimize the use and management of water resources and alleviate the impact of this ongoing overdraft, the region has adopted three major measures: agricultural planting structure adjustments and the promotion of agronomy water-saving techniques, strengthening of hydraulic engineering construction, and innovative management mechanisms. Field surveys showed that all measures were well implemented and that expected outcomes were generally achieved. Using accounting and conversion calculations based on power consumption under normal precipitation conditions, agricultural groundwater exploitation and overdraft governance results were determined. Agricultural groundwater overdraft was reduced by 188 million $\mathrm{m}^{3}$, which was $98.4 \%$ of the target goal. Among the groundwater overdraft governance measures, the most efficient three were (1) non-agricultural crops replacement (forestry), (2) planting pattern adjustments, and (3) the integration of water and fertilizer-vegetable. The implementation of these three measures should be enhanced in future governance. However, considering the area and total governance capacity, spring irrigation of wheat and replacement by surface water are the two most important water-saving measures, which are required to further strengthen the management and implementation effect. As compared to 2015, confined groundwater levels around Hengshui City during 2016 tended to rebound, with an average rise of $4.92 \mathrm{~m}$. The largest rebound in groundwater depth occurred at Wuyi County and Jizhou City, where groundwater levels increased by 6.29 and $6.63 \mathrm{~m}$, respectively. As compared to 2014, the average groundwater levels around Hengshui City rose by $8.37 \mathrm{~m}$. These data indicate that there is a general recharge in the confined groundwater in the major parts of the pilot areas.

Ongoing groundwater over-exploitation has resulted in constant declines in groundwater levels, which cannot be restored within a short period. Considering the hysteretic nature of the groundwater response to recharge, groundwater recovery will be a slow process. Declines will likely slow and reach a balanced state, followed by a gradual rebound. This lag period is a natural scientific phenomenon and, therefore, governance and restoration measures will need to be in effect over an extended period to have a lasting impact on groundwater resources.

Pilot areas for overdraft governance comprise only a small part of Hengshui City. Consequently, there is a limited impact in terms of these governance measures on the groundwater levels of the entire city. Groundwater levels in non-pilot areas will be gradually impacted by variations in pilot areas, but their influence will be slight. If over-exploitation continues in non-pilot areas, then groundwater levels in pilot areas may be deleteriously impacted. Therefore, the governance of groundwater overdraft must be performed continuously for a long period. 
Based on the measurable success of current governance measures, further groundwater comprehensive governance is warranted. Specific proposals could be as follows: (1) we must pay significantly more attention to the selection of projects that should be easy to implement in practice. During the investigation, we found that micro-sprinkling irrigation and the integration of water and fertilizer were not widely accepted by farmers. (2) At present, the governance measures include one-year effect measures, such as planting pattern adjustments, thirty-year effect measures, such as a surface water replacement project, and long-term institutional mechanisms construction. We suggest that future governance should focus more on long-term benefit projects. (3) We must strengthen the measurement of groundwater consumption, evaluate the performance of different governance measures in different regions, promote the establishment of dual control systems for groundwater levels, and regularly report the impact of these measures to the public. Based on these proposals, the measures are more likely to receive community support. (4) Measures should speed up the replacement of external water sources (such as the use of water from the South-to-North Water Diversion Project) and reduce the amount of groundwater extracted from urban industries and households. (5) Based on ensuring food security, a red line for the planting area of crops with high irrigation demand, such as wheat, should be established to prevent the excessive consumption of water resources.

Author Contributions: Y.Z. (Yong Zhao) and L.W. designed the study. H.L. and Y.Z. (Yongnan Zhu) performed the experiments. Q.W. and S.J. contributed to data collection. Y.Z. (Yong Zhao) and L.W. analyzed the date and drafted the manuscript. J.Z. and P.H. reviewed and edited the final version of the manuscript. All authors have read and agreed to the published version of the manuscript.

Funding: This research was funded by the National Key Research and Development Program of China (Grant No. 2016YFC0401407), the Basic Research Fund Project of China IWHR (Grant No. WR0145B622017), and the International Science and Technology Cooperation Program of China (Grant No. 2016YFE0102400).

Acknowledgments: We would like to thank Hengshui City, Taocheng District, Jizhou City, Shenzhou City, Raoyang County, Wuqiang County, Fucheng County, Wuyi County, Jing County, Zaoqiang County, and the Gucheng County water resources bureau for offering their data for use in this study. We are grateful to the editor and anonymous reviewers.

Conflicts of Interest: The authors declare no conflicts of interest.

\section{References}

1. Zektser, I.S.; Everett, L.G. Groundwater and the Environment: Applications for the Global Community; CRC Press: Boca Raton, FL, USA, 2000; pp. 10-60.

2. Jun, X.; Yongyong, Z. Water security in north China and countermeasure to climate change and human activity. Phys. Chem. Earth 2008, 33, 359-363.

3. Liu, C.; Yu, J.; Kendy, E. Groundwater exploitation and its impact on the environment in the North China Plain. Water Int. 2001, 26, 265-272.

4. Llamas, M.R.; Martínez-Santos, P. Intensive groundwater use: Silent revolution and potential source of social conflicts. J. Water Resour. Plan. Manag. 2005, 131, 337.

5. Sophocleous, M. Environmental implications of intensive groundwater use with special regard to streams and wetlands. In Intensive Use of Groundwater: Challenges and Opportunities; CRC Press: Boca Raton, FL, USA, 2002; pp. 93-112.

6. Deb, P.; Kiem, A.S.; Willgoose, G. A linked surface water-groundwater modelling approach to more realistically simulate rainfall-runoff non-stationarity in semi-arid regions. J. Hydrol. 2019, 575, 273-291.

7. Jiménez, A.; Saikia, P.; Giné, R.; Avello, P.; Leten, J.; Lymer, B.L.; Schneider, K.; Ward, R. Unpacking water governance: A framework for practitioners. Water 2020, 12, 827-847.

8. Jacobs, K.; Holway, J. Managing for sustainability in an arid climate: Lessons learned from 20 years of groundwater management in Arizona, U.S.A. Hydrogeol. J. 2004, 12, 52-65.

9. Lautze, J.; de Silva, S.; Giordano, M.; Sanford, L. Putting the cart before the horse: Water governance and IWRM. Nat. Resour. Forum 2011, 35, 1-8.

10. United Nations World Water Assessment Programme (WWAP). Water: A Shared Responsibility; The United Nations World Water Development Report 2; United Nations Educational, Scientific and Cultural Organization (UNESCO): Paris, France, 2006. 
11. World Bank. Governance and Development (English); The World Bank: Washington, DC, USA, 1992.

12. Ekardt, F.; Jacobs, B.; Stubenrauch, J.; Garske, B. Peatland Governance: The Problem of Depicting in Sustainability Governance, Regulatory Law, and Economic Instruments. Land 2020, 9, 83-107.

13. López-Gunn, E. Groundwater governance and social capital. Geoforum 2012, 43, 1140-1151.

14. de Castro-Pardo, M.; Fernández Martínez, P.; Martínez Guaita, J.M.; Martín Martín, J.M. Modelling Natural Capital: A Proposal for a Mixed Multi-criteria Approach to Assign Management Priorities to Ecosystem Services. Contemp. Econ. 2020, 14, 22-37.

15. Sophocleous, M. Review: Groundwater management practices, challenges, and innovations in the High Plains aquifer, USA—Lessons and recommended actions. Hydrogeol. J. 2010, 18, 559-575.

16. Zektser, S.; Loaiciga, H.A.; Wolf, J.T. Environmental impacts of groundwater overdraft: Selected case studies in the southwestern United States. Environ. Geol. 2005, 47, 396-404.

17. Kinzelbach, W.; Bauer, P.; Siegfried, T.; Brunner, P. Sustainable groundwater management—Problems and scientific tool. Episodes 2003, 26, 279-284.

18. Corwin, D.L.; Vaughan, P.J.; Loague, K. Modeling nonpoint source pollutants in the vadose zone with GIS. Environ. Sci. Technol. 1997, 31, 2157-2175.

19. Gogu, R.C.; Hallet, V.; Dassargues, A. Comparison of aquifer vulnerability assessment techniques. Application to the Néblon river basin (Belgium). Environ. Geol. 2003, 44, 881-892.

20. Zwahlen, F. Vulnerability and Risk Mapping for the Protection of Carbonate (Karst) Aquifers; COST Action 620, Final report; Publications of the European Communities: Brüssel, Luxemburg, 2003; p. 297.

21. Ong'or, B.T.; Long-cang, S. Groundwater overdraft vulnerability and environmental impact assessment in Arusha. Environ. Geol. 2007, 51, 1171-1176.

22. Kulkarni, H.; Shankar, P.; Krishnan, S. Groundwater governance: Backing CPR principles with a process-based approach. In Proceedings of the Thirteenth Biennial Conference of the International Association for the Study of the Commons, Hyderabad, India, 10-14 January 2011; pp. 10-14.

23. Molle, F. Development Trajectories of River Basins, a Conceptual Framework; Research Report 72; International Water Management Institute: Battaramulla, Sri Lanka, 2003.

24. Konikow, L.F.; Kendy, E. Groundwater depletion: A global problem. Hydrogeol. J. 2005, 13, 317-320.

25. Scott, C.A.; Shah, T. Groundwater overdraft reduction through agricultural energy policy: Insights from India and Mexico. Int. J. Water Resour. Dev. 2004, 20, 149-164.

26. Cory, D.C.; Evans, M.E.; Leones, J.P.; Wade, J.C. The role of agricultural groundwater conservation in achieving zero overdraft in Arizona. J. Am. Water Resour. Assoc. 1992, 28, 889-901.

27. Kimrey, J.O. Artificial recharge of groundwater and its role in water management. Desalination 1989, 72 , $135-147$.

28. Booker, J.F.; Howitt, R.E.; Michelsen, A.M.; Young, R.A. Economics and the modeling of water resources and policies. Nat. Resour. Model. 2012, 25, 168-218.

29. Harou, J.J.; Lund, J.R. Ending groundwater overdraft in hydrologic-economic systems. Hydrogeol. J. 2008, 16, 1039.

30. MacEwan, D.; Cayar, M.; Taghavi, A.; Mitchell, D.; Hatchett, S.; Howitt, R. Hydroeconomic modeling of sustainable groundwater management. Water Resour. Res. 2017, 53, 2384-2403.

31. Harou, J.J.; Lund, J.R. Economic and Water Management Effects of a no Overdraft Policy: California's Tulare Basin. Available online: http://aguas.igme.es/igme/ISGWAS/Ponencias\%20ISGWAS/4-Lund.pdf (accessed on 15 April 2020).

32. Davidsen, C.; Liu, S.; Mo, X.; Rosbjerg, D.; Bauer-Gottwein, P. The cost of ending groundwater overdraft on the North China Plain. Hydrol. Earth Syst. Sci. 2016, 20, 771-785.

33. Kinzelbach, W.; Aeschbach, W.; Alberich, C.; Goni, I.B.; Beyerle, U.; Brunner, P.; Chiang, W.-H.; Rueedi, J.; Zoellmann, K.A. Survey of Methods for Groundwater Recharge in Arid and Semiarid Regions; Early Warning and Assessment Report Series, UNEP/DEWA/RS.02-2; United Nations Environment Programme: Nairobi, Kenya, 2002.

34. Rabelo, J.L.; Wendland, E. Assessment of groundwater recharge and water fluxes of the Guarani Aquifer System, Brazil. Hydrogeol. J. 2009, 17, 1733-1748.

35. Scanlon, B.R.; Healy, R.W.; Cook, P.G. Choosing appropriate techniques for quantifying groundwater recharge. Hydrogeol. J. 2002, 10, 18-39. 
36. Demlie, M. Assessment and estimation of groundwater recharge for a catchment located in highland tropical climate in central Ethiopia using catchment soil-water balance (SWB) and chloride mass balance (CMB) techniques. Environ. Earth Sci. 2015, 74, 1137-1150.

37. Croteau, A.; Nastev, M.; Lefebvre, R. Groundwater Recharge Assessment in the Chateauguay River Watershed. Can. Water Resour. J. 2010, 35, 451-468.

38. Kirn, L.; Mudarra, M.; Marín, A.; Andreo, B.; Hartmann, A. Improved assessment of groundwater recharge in a mediterranean karst region: Andalusia, Spain. In EuroKarst 2016, Neuchâtel; Springer: Cham, Switzerland, 2017; pp. 117-125.

39. Dripps, W.R. An integrated field assessment of groundwater recharge. Open Hydrol. J. 2012, 6, 15-22.

40. Department of water resources of Hebei Province. Pilot Program of Comprehensive Treatment of Groundwater Overdraft in Hebei Province; Department of water resources of Hebei Province: Beijing, China, 2015.

41. Allen, R.G. Using the FAO-56 dual crop coefficient method over an irrigated region as part of an evapotranspiration intercomparison study. J. Hydrol. 2000, 229, 27-41.

42. Allen, R.G.; Smith, M.; Perrier, A.; Pereira, L.S. An update for the definition of reference evapotranspiration. ICID Bull. 1994, 43, 1-34.

43. Svensson, C.; Jones, D.A. Review of rainfall frequency estimation methods. J. Flood Risk Manag. 2010, 3, 296-313.

(C) 2020 by the authors. Licensee MDPI, Basel, Switzerland. This article is an open access article distributed under the terms and conditions of the Creative Commons Attribution (CC BY) license (http://creativecommons.org/licenses/by/4.0/). 